\title{
PRODUCTION OF NURSING THESIS AND DISSERTATIONS IN PORTUGAL, 2000-2010: A BIBLIOMETRIC STUDY ${ }^{1}$
}

\author{
Maria Aparecida Baggio², Manuel Alves Rodrigues³, Alacoque Lorenzini Erdmann ${ }^{4}$, Maria do Céu Aguiar \\ Barbieri Figueiredo ${ }^{5}$, Margarida Maria da Silva Vieira ${ }^{6}$
}

\begin{abstract}
${ }^{1}$ Production from a sandwich Ph.D course under the auspices of the National Council for Scientific and Technological Development $(\mathrm{CNPq})$ at the Nursing School of Coimbra, Portugal.

2 Ph.D. in Nursing, Postgraduate Program in Nursing (PEN), Federal University of Santa Catarina (UFSC). Professor at the State University of West Paraná (UNIOESTE). Paraná, Brasil. E-mail: mariabaggio@yahoo.com.br

${ }^{3}$ Ph.D. in Education. Principal coordinating professor of the Coimbra Nursing School, Portugal. E-mail: demar7@gmail.com

${ }^{4}$ Ph.D. in Philosophy of Nursing. Full Professor of the Department of Nursing and PEN/UFSC. Researcher 1A of the CNPq. Santa Catarina, Brazil. E-mail: alacoque@newsite.com.br

${ }^{5}$ Ph.D. in Nursing Sciences. Coordinating professor of the Porto Nursing School. Portugal. E-mail: ceubarbieri@esenf.pt

${ }^{6}$ Ph.D. in Philosophy. Associate Professor of the Health Sciences Institute (Porto) of the Catholic University of Portugal. Portugal. E-mail: mmvieira@porto.ucp.pt
\end{abstract}

\begin{abstract}
The study identifies Portuguese nursing research, produced in the period 2000 - 2010, published via Master's dissertations and doctoral theses, analyzed according to the following variables: institution training masters and doctors, studies' distribution by institution, study supervisors and co-supervisors with their respective titles, supervisors' productions, keywords/descriptors, topics studied, theoretical framework, methodological framework, subjects, data collection and data analysis. In this exploratory, descriptive and bibliometric study, dissertations from the Catholic University of Portugal and the Institute of Biomedical Sciences of the University of Porto were collected, as were doctoral theses from both these institutions and the University of Lisbon, totalling 41 theses and 273 dissertations. The results describe the theoretical, methodological and bibliometric aspects of the strictu sensu scientific production of Portuguese nursing. It is concluded that nurse researchers, in having knowledge of the specific areas of the studies, can improve them to achieve quality and excellence of the training of Master's and doctoral students.
\end{abstract}

KEYWORDS: Nursing. Scientific research and technological development. Bibliometrics.

\section{PRODUÇÕES DE TESES E DISSERTAÇÕES DA ENFERMAGEM EM PORTUGAL DE 2000 AO 2010: ESTUDO BIBLIOMÉTRICO}

RESUMO: O estudo identifica as pesquisas da enfermagem portuguesa, produzidas no período de 2000 a 2010, divulgadas por meio de dissertações de mestrado e de teses de doutorado, analisadas pelas seguintes variáveis: instituição formadora, distribuição dos estudos por instituição, orientador e co-orientador do estudo com respectiva titulação, produtividade dos orientadores, palavraschave/descritores, temas estudados, referencial teórico, referencial metodológico, sujeitos, coleta e análise dos dados. O estudo é do tipo exploratório, descritivo, bibliométrico, realizado a partir do levantamento das dissertações da Universidade Católica Portuguesa e do Instituto de Ciências Biomédicas da Universidade do Porto e das teses de doutorado dessas instituições e da Universidade de Lisboa, totalizando 41 teses e 273 dissertações. Nos resultados, são discriminados aspectos teóricos, metodológicos e bibliométricos da produção científica stricto sensu da enfermagem portuguesa. Conclui-se que os enfermeiros pesquisadores, ao terem conhecimento das especificidades dos estudos, podem aperfeiçoá-las para a qualidade e excelência da formação de mestres e doutores.

PALAVRAS CHAVE: Enfermagem. Pesquisa científica e desenvolvimento tecnológico. Bibliometria.

\section{PRODUCCIONES DE DISERTACIONES Y TESIS DE ENFERMERÍA EN PORTUGAL DE 2000-2010: ESTUDIO BIBLIOMÉTRICO}

RESUMEN: El estudio identifica la investigación de enfermería portugués producido en el período 2000 a 2010, publicado por disertaciones de maestría y tesis de doctorado, analizados por medio de las variables: institución formadora, distribución de los estudios por institución, orientador y co-orientador del estudio con respectiva titulación, productividad de los asesores, palabras clave/ descriptores, temas estudiados, referencial teórico, referencial metodológico, sujetos, recolección y análisis de los datos. El estudio es de tipo exploratorio, descriptivo, bibliométrico, realizado mediante el levantamiento de las disertaciones de maestría de la Universidad Católica Portuguesa y del Instituto de Ciencias Biomédicas de la Universidad de Oporto y de las tesis de doctorado de dichas instituciones y de la Universidad de Lisboa, se analizó un total de 41 tesis y 273disertaciones. En los resultados están discriminados aspectos teóricos, metodológicos y bibliométricos de la producción científica stricto sensu de la enfermería portuguesa. Se concluyó que los enfermeros investigadores, al tener conocimiento de las especificidades de los estudios, pueden perfeccionarlos con consecuencias en la calidad y la excelencia de la formación de maestros y doctores.

PALABRAS CLAVE: Enfermería. Investigación científica y desarrollo tecnológico. Bibliometría. 


\section{INTRODUCTION}

Academic Master's courses* in Nursing/ Nursing Sciences, in Portugal, have been offered by the Catholic University of Portugal (UCP), since 1991; and by the Abel Salazar Institute of Biomedical Sciences (ICBAS), of the University of Porto, in partnership with the Porto Nursing School, since 1993. These institutions have also offered doctorates in Nursing since 2004 and 2001, respectively. The University of Lisbon (UL) has offered a doctorate in Nursing, in partnership with the Lisbon Nursing School, since 2004.

The UCP began providing a Master's in Nursing Sciences in 1991, in Lisbon, whose dissertations were presented in 2000, 2001 and 2002. In 2004, a new model of training, termed the Master's in Nursing, began with groups in the cities of Porto and Sintra, which was adapted to the Bologna Accords in 2007, without, however, large changes in relation to the prior model, both Master's courses being academic. Thus, in 2007/2008, the UCP presented a new Master's course, undertaken in four specialities of knowledge, namely: History and philosophy of nursing, Education in nursing; Management of nursing services; and Advanced nursing.

In 2004, the UCP's doctoral course in nursing was created, adapted to the Bologna Accords, in 2007, as was the Master's course in nursing. The Doctorate in Nursing offers the same areas of specialization as the Academic Master's course in Nursing, with Management of Health Centers being added to the area of Management. ${ }^{2}$

In 1993, the ICBAS of the University of Porto began offering its Master in Nursing Sciences course, and, in 2001, a Doctorate in Nursing Sciences. The Master's and Doctorate programs are the result of a partnership between the ICBAS, of the University of Porto, and the Nursing School of Porto, and are regulated by a protocol between the two institutions and by the Bologna Accords. ${ }^{3}$

In 2004, the UL created its Doctorate Program in Nursing, resulting from a protocol between the University and the Lisbon Nursing School, which originated from the fusion of four public nursing schools in Lisbon. ${ }^{4}$
The production of knowledge disseminated via Master's dissertations and doctoral theses, in conjunction with other investigations undertaken, represents the development of scientific research, of the processes of knowledge, and of the nursing researchers; the role of the stricto sensu programs is the training of highly qualified and productive Master's and doctoral students in Nursing, geared towards scientific development as well as the qualification of Nursing teaching and practice in Portugal. ${ }^{5}$

Due to there having been development of Portuguese scientific production, in the categories of nursing dissertations and theses, since 1991 and 2001 respectively, and to knowledge not being available regarding the totality and the specific characteristics of the same through investigation, there was interest in information on the studies already produced being systematized. In this way, the question was asked: how is the production of dissertations and theses by the institutions qualifying Masters and Doctors of Nursing in Portugal? How many studies have been produced since the opening of the academic Master's courses and doctorates in Nursing? What are the main issues addressed in the Nursing dissertations and theses? What are the methodological aspects used in the studies undertaken, specifically in relation to the theoretical-methodological framework, research subjects, and collection and analysis of data? Are the key words/descriptors mentioned in the studies? What are the academic titles of the studies' supervisors? Of these supervisors, how is their contribution to the production of the studies verified?

Considering the questions which led to the undertaking of the present investigation, the objectives are to identify the Portuguese Nursing dissertations and theses, presented to obtain the qualification of Master and Doctor in Nursing and Nursing Sciences, and to analyze the dissertations and theses in relation to the variables: institution where the student was being trained, distribution of the studies by institution, supervisor and cosupervisor of the study with their respective titles, the productions undertaken under the supervision of the supervisors, keywords/descriptors, topics

\footnotetext{
* An Academic Master's course aims to involve the student in using the scientific method for research in areas of academic interest, in contrast with the Professional Master's course, in which the student uses the scientific method to solve organizations' actual problems. Translator's note.
} 
studied, theoretical framework, methodological framework, subjects and collection and analysis of data.

\section{METHODOLOGY}

The study is bibliometric, descriptive and retrospective, and was undertaken through a review of the literature available.

When produced and published for the scientific community, written documents arising from scientific activity are sources of indicators of the stage of development of an area of knowledge, ${ }^{6}$ also offering data for the researchers to identify the principal advances of science, and the fields which need greater investment in research. Bibliometrics, as a methodology, allows one to obtain information regarding the processes of written communication, in this case, in the form of theses and dissertations; it also provides, through the results acquired, support for formulating scientific and technological policies for the area of Nursing. ${ }^{7}$

For undertaking this study, a survey was made of the Academic Master's dissertations of the UCP and of the ICBAS, of the doctoral theses from the institutions cited above and the UL, relating to the period 2000-2010. Studies available online in the University of Porto and University of Lisbon's open repository were consulted, as were studies available in print in the institutions' libraries, institutional CDs/DVDs and studies obtained via email from authors whose studies were not available in other formats. The following were considered: data provided on the front page, the inside back cover, and the texts of the abstracts of the dissertations and theses located. There were two cases in which access was obtained only to the study's catalog card, made available by institutions' libraries. The data were inserted into an Excel spreadsheet. Each variable was analyzed separately and by the relationships between variables when relevant.

\section{RESULTS}

33 doctoral theses in Nursing/Nursing Sciences, and 201 Master's dissertations presented at ICBAS were identified, as were three theses and 72 dissertations presented at the UCP, and five theses at the UL. As a result, in total, for Nursing, 41 theses and 273 dissertations were presented between 2000 and 2010 in Portugal.

The UCP has three doctoral theses, approved in 2010. The UL has five theses between 2008 and 2010, and ICBAS, 33 theses between 2001 and 2009. Figure 1 shows the development of the theses in the period investigated.

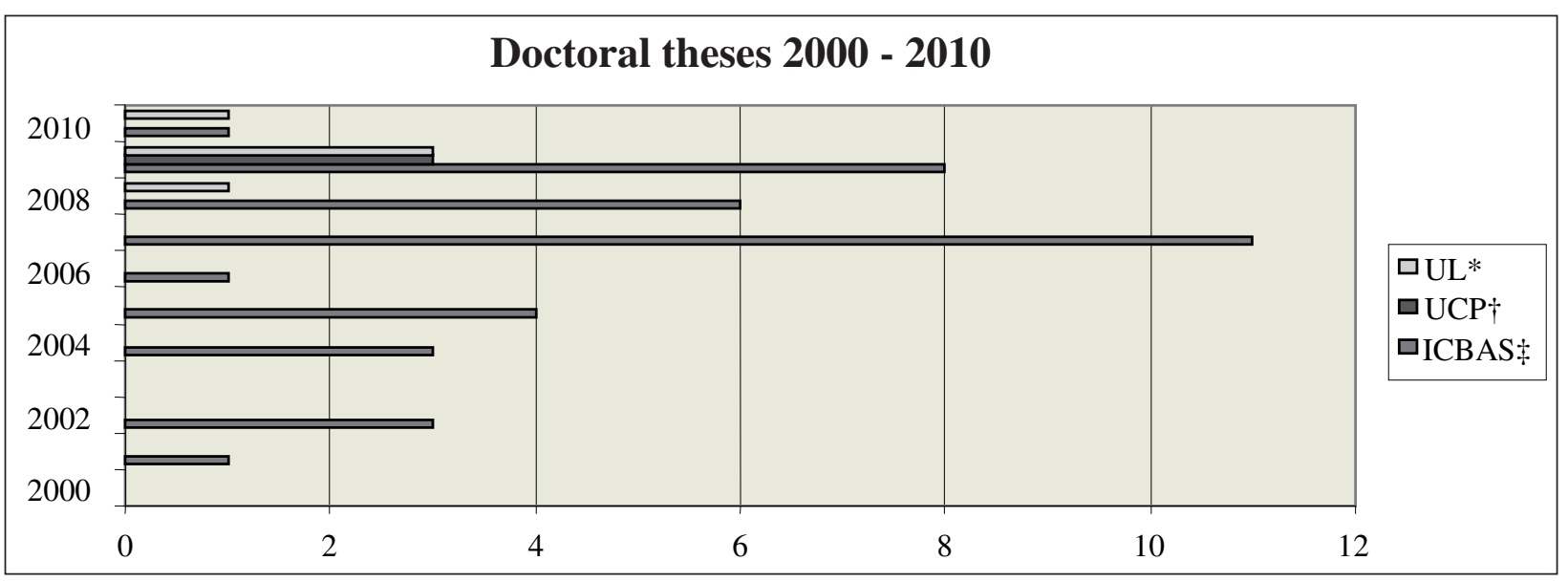

* UL: University of Lisbon; †UCP: Catholic University of Portugal; ¥ICBAS: Abel Salazar Institute of Biomedical Sciences.

Figure 1 - Doctoral theses referent to the period 2000-2010, presented to ICBAS and UCP. Portugal, 2011

The UCP presented 21 Master's studies between 2000 and 2002; 51 studies between 2007 and 2010. ICBAS has 201 studies presented between
2000 and 2010. Figure 2 illustrates the development of the dissertations during the period investigated. 


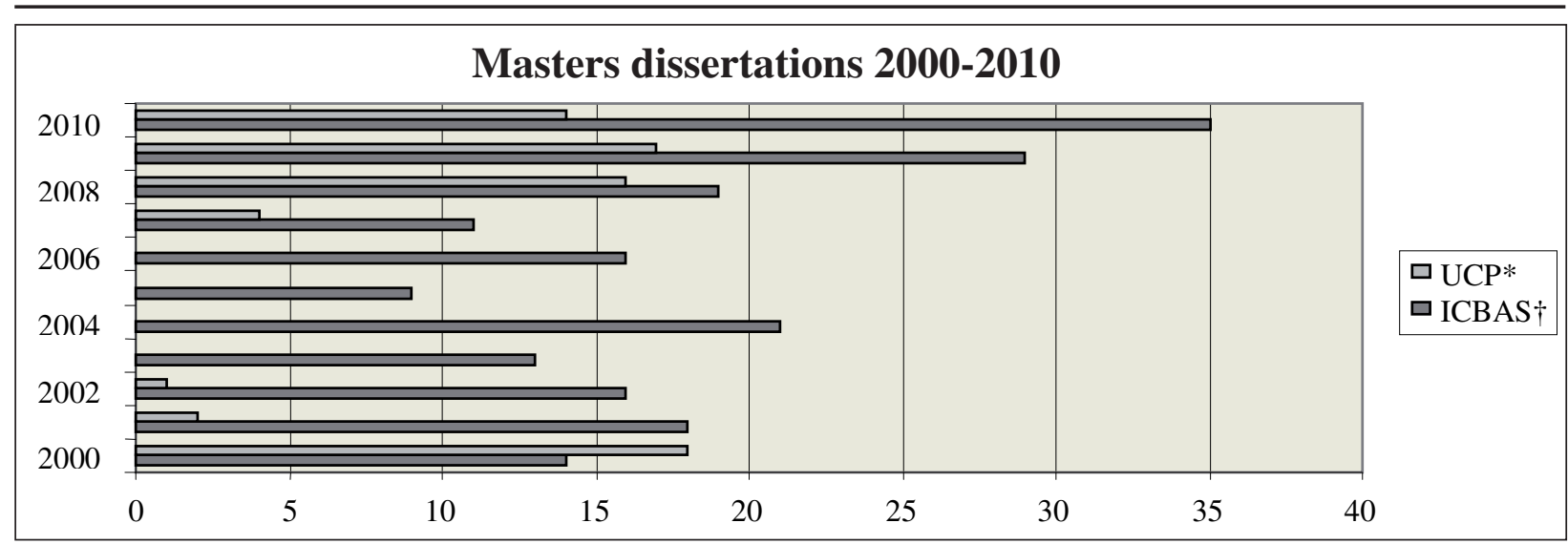

* UCP: Catholic University of Portugal; †ICBAS: Abel Salazar Institute of Biomedical Sciences.

Figure 2 - Master's dissertations referent to the period 2000-2010, presented at ICBAS and UCP. Portugal, 2011

Regarding the topic, issues related to older adults stand out in the dissertations and theses, with $26(9.5 \%)$ and six (14.6\%) studies, respectively. Regarding dissertations preferred by the researchers, issues relating to the family have 23 $(8.4 \%)$ and $6(14.6 \%)$ studies; adolescents, $14(5.1 \%)$ and four $(9.7 \%)$ studies; obstetrics, $23(8.4 \%)$ and four $(9.7 \%)$ studies; and nursing training, $18(6.5 \%)$.

Regarding the theses, besides issues related to the older adult, the family, the adolescent and obstetrics, three $(7.2 \%)$ studies addressed the issue of Information Systems, two (4.8\%), pediatrics and neonatology, two $(4.8 \%)$ dealt with training, two $(4.8 \%)$ related to mood and happiness, two $(4.8 \%)$ related to oncology/cancer, one (2.4\%) addresses terminal illnesses, one $(2.4 \%)$ is about orthopedics/rehabilitation, one $(2.4 \%)$ deals with health promotion in the community context, one $(2.4 \%)$ is about the perioperative period, one (2.4\%) about psychiatry, one $(2.4 \%)$ about ethics, one $(2.4 \%)$ about alcohol/drug addiction, one (2.4\%) about home care, one $(2.4 \%)$ about clinical decisionmaking and one $(2.4 \%)$ relates to death.

Regarding the topics of the dissertations, besides those related to the older adult, the family, the adolescent, obstetrics and nursing training, 12 studies $(4.3 \%)$ were identified on pediatrics and neonatology, 12 (4.3\%) on pain and/or chronic illness, 12 (4.3\%) on oncology/cancer, 11 (4\%) on terminal illness, nine $(3.2 \%)$ on acute pain, eight $(2.9 \%)$ on quality of nursing care, eight $(2.9 \%)$ on orthopedics/rehabilitation, seven $(2.5 \%)$ on the nursing process, seven $(2.5 \%)$ on health promotion/community context, six $(2.1 \%)$ on autonomy, six $(2.1 \%)$ on professional satisfaction and values, five $(1.8 \%)$ on therapeutic regimes, five $(1.8 \%)$ on the emergency service, five $(1.8 \%)$ on the perioperative period, five $(1.8 \%)$ on psychiatry, five $(1.8 \%)$ on embracement, four $(1.4 \%)$ on death, four (1.4\%) on sharing of nursing information, four (1.4\%) on management/administration/leadership, four $(1.4 \%)$ on ostomies/wounds, three $(1.0 \%)$ on cardiology, three $(1.0 \%)$ on ethics, two $(0.7 \%)$ on clinical errors, two $(0.7 \%)$ on urinary tracts, two $(0.7 \%)$ on spirituality, two $(0.7 \%)$ on alcohol/drug addiction, two $(0.7 \%)$ on helping relationships and $14(5.1 \%)$ studies discussed other issues, there being one for each study. It is appropriate to state that the titles of the Master's and doctoral studies were considered to determine the topics.

It may be ascertained that, of the 41 theses, $28(68.2 \%)$ had a supervisor and co-supervisor and two theses $(4.8 \%)$ had two co-supervisors, all with the title of doctor. Of the 273 dissertations, 26 (9.5\%) were co-supervised. Regarding academic title, of the 273 supervisors of Master's dissertations, $227(83.1 \%)$ are Doctors, 24 (8.7\%) are Masters, eight $(2.9 \%)$ did not state the titles and $14(5.1 \%)$ dissertations did not name, or it was not possible to identify, the supervisor. Of the 26 $(9.5 \%)$ co-supervisors of Master's dissertations, three (1\%) are Doctors, 15 (5.4\%) are Masters, and eight $(2.9 \%)$ did not state the titles. Regarding the academic titles of the supervisors of Master's dissertations, in ICBAS, all supervisors have had the title of Doctor since 2006. It is known that supervision of Master's dissertations at UCP has been undertaken exclusively by Doctors, since the beginning of the course in 2000. However, five studies did not mention the supervisor and two did not mention the supervisors' academic titles.

Of the supervisors of doctorates, five $(12 \%)$ supervised $23(56 \%)$ of the $41(100 \%)$ theses pro- 
Baggio MA, Rodrigues MA, Erdmann AL, Figueiredo MCAB, Vieira MMS

duced. One professor was responsible for $11(27 \%)$ of the total of supervision undertaken and $18(44 \%)$ professors were responsible for the supervision of a single $(2.4 \%)$ thesis. One $(2.4 \%)$ thesis did not state the supervisor.

Of the supervisors of Master's dissertations, five undertook the supervision of 98 (35.8\%) of the $273(100 \%)$ studies, with emphasis for two professors with $23(8.4 \%)$ supervisions each. 20 professors, together, supervised 161 (58.9\%) dissertations and each one supervised between two and 11 supervisions. The supervisors' names were not stated in $14(5.1 \%)$ dissertations analyzed.

Of the 41 theses, 11 (26\%) presented keywords and/or descriptors. Ten theses $(24.3 \%)$ have at least one exact descriptor or a synonym, in accordance with the Descriptors in Health Sciences (DeCS) and Medical Subject Headings (MeSH). The key words and/ or descriptors were added up and in total there are 59. Of these, eight are exact descriptors and four are synonyms of DeCS/MeSH descriptors.

Of the 273 dissertations, 67 (24.5\%) present keywords and/or descriptors, of which 52 (19\%) state at least one descriptor or synonym in accor- dance with DeCS/MeSH. There is a total of 306 keywords and/or descriptors from all of the dissertations which state them, of which 95 are exact descriptors and 18 synonyms of DeCS/MeSH descriptors. Besides these, seven descriptors were identified which were inadequately stated regarding how they were written, that is, the descriptor in the plural when the term is located in the singular and vice versa. For example, 'older adult' is the exact term, but the study states 'older adults'. In the case of the theses, only one similar event occurred. The descriptor 'Nursing' was not identified in the doctoral theses in Nursing, although the same was identified in 17 (6.2\%) of 273 dissertations.

Regarding the methodological framework of the Master's and doctoral studies in Nursing, there are studies which use qualitative, quantitative, and quanti- and qualitative methodologies. Of the 41 doctoral theses, $19(46.3 \%)$ used a qualitative methodology, five $(12.1 \%)$ a quantitative methodology, and nine $(21.9 \%)$ a quanti-qualitative methodology. One thesis (2.4\%) did not have an abstract and seven $(17 \%)$ did not explain, or it was not possible to identify, the research method used. In Table 1, the methods identified in the theses are itemized.

Table 1 - Research methods used in the doctoral theses, 2000-2010. Portugal, 2011

\begin{tabular}{|c|c|c|}
\hline Variables & $\mathbf{n}$ & $\%$ \\
\hline \multicolumn{3}{|l|}{ Qualitative studies } \\
\hline Qualitative approach & 1 & $2.4 \%$ \\
\hline Grounded Theory and investigation-action & 1 & $2.4 \%$ \\
\hline Exploratory, descriptive & 2 & $4.8 \%$ \\
\hline Case study & 2 & $4.8 \%$ \\
\hline Phenomenology & 3 & $7.3 \%$ \\
\hline Grounded Theory & 4 & $9.7 \%$ \\
\hline Investigation-action & 6 & $14.6 \%$ \\
\hline \multicolumn{3}{|l|}{ Quantitative studies } \\
\hline Experimental & 1 & $2.4 \%$ \\
\hline Exploratory and validation of instrument & 1 & $2.4 \%$ \\
\hline $\begin{array}{l}\text { Descriptive, correlational, involving translation and adaptation of scales and psychometric evaluation } \\
\text { of questionnaires and quasi-experimental }\end{array}$ & 1 & $2.4 \%$ \\
\hline Descriptive, correlational & 2 & $4.8 \%$ \\
\hline \multicolumn{3}{|l|}{ Quanti-qualitative studies } \\
\hline Quali/Quanti & 1 & $2.4 \%$ \\
\hline Exploratory, quasi-experimental & 1 & $2.4 \%$ \\
\hline Exploratory, descriptive, transversal & 1 & $2.4 \%$ \\
\hline Mixed (quali and quantitative), transversal & 1 & $2.4 \%$ \\
\hline Grounded Theory and descriptive, correlational & 1 & $2.4 \%$ \\
\hline Exploratory, descriptive, with multiple triangulation of methods & 1 & $2.4 \%$ \\
\hline Exploratory, descriptive, transversal, experimental and phenomenology & 1 & $2.4 \%$ \\
\hline Exploratory, descriptive, retrospective, transversal and phenomenology & 1 & $2.4 \%$ \\
\hline $\begin{array}{l}\text { Phenomenology, validity and analysis of reliability of instruments Recording of CD with input from } \\
\text { the literature and validation, quasi-experimental }\end{array}$ & 1 & $2.4 \%$ \\
\hline Did not have an abstract & 1 & $2.4 \%$ \\
\hline Did not make clear, or was not possible to identify, the research method used & 7 & $17 \%$ \\
\hline
\end{tabular}


In relation to the 273 Master's dissertations, the present study identified $116(58.6 \%)$ with qualitative methodologies, $79(28.9 \%)$ as quantitative and $15(5.4 \%)$ as quanti- and qualitative. Of the total of dissertations, six $(2.1 \%)$ did not have an abstract and $13(4.7 \%)$ did not make clear, or it was not possible to identify, the research method used. When the studies stated that they were 'descriptive', 'exploratory' and/or 'exploratory-descriptive', but the abstract did not state the type of methodological approach, the relationship between the objective, data collection instrument, analysis and results was used to understand the approach used. The methods can be seen in table 2 .

Table 2 - Research methods used in Master's dissertations, 2000-2010. Portugal, 2011

\begin{tabular}{|c|c|c|}
\hline Variables & $\mathrm{n}$ & $\%$ \\
\hline \multicolumn{3}{|l|}{ Qualitative studies } \\
\hline Ethnobiography & 1 & $0.3 \%$ \\
\hline Phenomenography & 1 & $0.3 \%$ \\
\hline Opinion study & 1 & $0.3 \%$ \\
\hline Methodological investigation & 1 & $0.3 \%$ \\
\hline Interpretative & 1 & $0.3 \%$ \\
\hline Social representation & 2 & $0.7 \%$ \\
\hline Investigation-action & 3 & $1 \%$ \\
\hline Historical research & 3 & $1 \%$ \\
\hline Case study & 4 & $1.4 \%$ \\
\hline Ethnography & 9 & $3.2 \%$ \\
\hline Qualitative approach & 12 & $4.3 \%$ \\
\hline Grounded Theory & 17 & $6.2 \%$ \\
\hline Phenomenology & 48 & $17.5 \%$ \\
\hline Exploratory, descriptive & 57 & $20.8 \%$ \\
\hline \multicolumn{3}{|l|}{ Quantitative studies } \\
\hline Methodological investigation & 1 & $0.3 \%$ \\
\hline Translation and validation of instrument & 1 & $0.3 \%$ \\
\hline Relational case study, repeated measures & 1 & $0.3 \%$ \\
\hline Cohort, prospective, incidence & 1 & $0.3 \%$ \\
\hline Retrospective, analytical, correlational & 1 & $0.3 \%$ \\
\hline Descriptive, exploratory, ex-post-facto & 1 & $0.3 \%$ \\
\hline Descriptive, analytical, comparative, quasi-experimental, transversal & 1 & $0.3 \%$ \\
\hline Descriptive, correlational, transversal, quasi-experimental & 1 & $0.3 \%$ \\
\hline Exploratory, descriptive, transversal, non-experimental & 1 & $0.3 \%$ \\
\hline Exploratory, descriptive, longitudinal & 1 & $0.3 \%$ \\
\hline Exploratory, descriptive, analytical, correlational, translation and validation of instrument & 1 & $0.3 \%$ \\
\hline Descriptive & 2 & $0.7 \%$ \\
\hline Descriptive, comparative, transversal & 2 & $0.7 \%$ \\
\hline Quasi-experimental & 3 & $1 \%$ \\
\hline Adaptation and validation of instrument & 3 & $1 \%$ \\
\hline Descriptive, observational, transversal & 3 & $1 \%$ \\
\hline Exploratory, descriptive, comparative & 3 & $1 \%$ \\
\hline Exploratory, descriptive, retrospective & 3 & $1 \%$ \\
\hline Quantitative approach & 3 & $1 \%$ \\
\hline Descriptive, correlational, transversal & 5 & $1.8 \%$ \\
\hline Exploratory, descriptive, correlational, non-experimental & 5 & $1.8 \%$ \\
\hline Exploratory, descriptive & 6 & $2.1 \%$ \\
\hline Exploratory, descriptive, analytical, correlational & 14 & $5.1 \%$ \\
\hline Exploratory, descriptive, analytical, transversal & 16 & $5.8 \%$ \\
\hline \multicolumn{3}{|l|}{ Quanti and qualitative studies } \\
\hline Qualitative, longitudinal, multi-case & 1 & $0.3 \%$ \\
\hline Investigation-action, descriptive, comparative & 1 & $0.3 \%$ \\
\hline
\end{tabular}


Exploratory, descriptive, retrospective, quali/quanti

Exploratory, descriptive, retrospective, transversal, quali/quanti

Exploratory, descriptive, quali/quanti

Descriptive, analytical, correlational, longitudinal, quali/quanti

Exploratory, descriptive, analytical, transversal, quali/quanti

Phenomenological and quantitative method

Quali/quanti methodology

Did not have an abstract

Did not make clear, or was not possible to identify, the research method used
$0.3 \%$

$0.3 \%$

$0.3 \%$

$0.3 \%$

$0.7 \%$

$1 \%$

$1.4 \%$

$2.1 \%$

$4.7 \%$
Regarding the theoretical framework, the analysis allowed the identification that, of the 41 theses, one (2.4\%) used Paulo Freire's Education by consciousness raising; one $(2.4 \%)$ used the ideas of Martin Heidegger; one (2.4\%) used the perspective of Jürgen Habermas; one (2.4\%) observed the Basic Needs Theory of Virginia Henderson; one $(2.4 \%)$ used Maynard's Model; one (2.4\%) studied the Theory of Stress, evaluation and conflict; one $(2.4 \%)$ observed the nursing Information Systems; one $(2.4 \%)$ mentioned the use of the theories of Peplau, Mayerof, Watson, Orlando, Benner, Chalifour and Phaneuf; one (2.4\%) used the Calgary family assessment and intervention models; one (2.4\%) used the Caring framework of Jean Watson, the Basic Needs Theory of Virginia Henderson, the Helping Relationship of Helene Lazure, and the Development of competencies, of Patricia Benner and Guy Le Botherf; one (2.4\%) used the conceptual structure of comfort, of Kolcaba's Middle Range Theory; one (2.4\%) study used the systemic Theory/Thinking/Model and also Christensen's model of partnership of care, the Activities of Daily Living model of Roper, Logan and Tierney, and Orem's selfcare model; two (4.8\%) studies used the systemic Theory/Thinking/Model of care as a theoretical framework; one (2.4\%) thesis did not have an abstract; and $26(63.4 \%)$ theses did not mention in the abstract, or did not use, a theoretical framework.

Of the 273 Master's studies, 26 (9.5\%) stated the theoretical framework(s) used, 241 (88.2\%) used and/or did not state the use of a theoretical framework, and six $(2.1 \%)$ did not have an abstract. The description of the theoretical frameworks used, and their associations, from which they were identified in the 26 Master's dissertations, are presented as follows: one $(0.3 \%)$ on Jean Watson; one $(0.3 \%)$ on Leininger; one $(0.3 \%)$ on Rogers; one $(0.3 \%)$ on Fiedler's Theory of Contingency and Maslow's Theory of Human Motivation; one $(0.3 \%)$ on social cognitive theory; one $(0.3 \%)$ on Symbolic Interactionism; one $(0.3 \%)$ on Kolcaba's comfort theory; one $(0.3 \%)$ on Roy's adaptation model; one $(0.3 \%)$ on the model of Rauen, Basto, Costa, Schon and Martin; one $(0.3 \%)$ on the Neuman systems model; one $(0.3 \%)$ on Tiffany Field's massage technique; one (0.3\%) on Spradley and Leininger; one $(0.3 \%)$ on Meleis and Bronfenbrenner; one $(0.3 \%)$ on Collière, Watson, and Parse; one $(0.3 \%)$ on the Helping Relationship of Peplau, Rogers, Laruze and Chalifour; one $(0.3 \%)$ on Plato, Aristotle, Kant, Merleau-Ponty and Lukacs; one $(0.3 \%)$ on Merleau-Ponty, Oiler, Erickson, Sampaio, Aberastury, Collière, Watson, Renaud and Ricoeur, among others; one $(0.3 \%)$ on Barreto, Brissos, Aristotle, Ricoeur, Fromm, Egan, Watson, Roach, Chalifour, Laruze and Merleau Ponty; one $(0.3 \%)$ on Leininger, Collière, Kerouac, Bogdan and Biklen, Lisete, Fradique Ribeiro, Martin Zurro and Cano Pérez, among others; one $(0.3 \%)$ on Quivy and Campenhoudt, Streubert and Carpenter, Ornelas et al., Moscovici, Guimeli, Moreira, Jesuíno, Jovchelovith and Abric; one $(0.3 \%)$ on Predisposing Reinforcing and Enabling Causes Educational Diagnosis and Evaluation (PRECEDE); two $(0.7 \%)$ on ICNP and three $(1 \%)$ on Anne Casey's partnership model of nursing care. It is assured that the name of the author/theory/ model respective to the theoretical framework was kept as stated in the theses and dissertations.

Based on the above, the main theoretical frameworks used stated in the Master's dissertations, whether associated with the other frameworks or not, were: Jean Watson, mentioned in four studies; Madeleine Leininger, in three; Merleau Ponty, in three; Marie-Françoise Collière, in three studies; Anne Casey's partnership model of care, also used in three studies; and Paul Ricoeur, used in two studies. In the theses, the main theoretical frameworks used were those of Virginia Henderson and Jean Watson, used in two studies, and of Complex systems, in three studies.

Regarding the subjects of the studies, in the doctoral theses these are principally participants who are nurses, and ill adults and students/young 
people/adolescents; while in the Master's dissertations, the research subjects are mainly nurses, ill adults, and families/caregivers.

In relation to the data collection instruments, relative to the total of the studies, combined or not, the most common is the use of interviews, mentioned in $15(36.5 \%)$ theses and in $146(53.4 \%)$ dissertations, while the questionnaire is present in $13(31.7 \%)$ theses and $66(24.1 \%)$ dissertations. Other means of data collection also used in the theses were: observation, in eight $(19.5 \%)$ theses, scales in six $(14.6 \%)$, documents in three $(7.3 \%)$, and other instruments, such as: psychometric tests, field diaries, focus groups, discussion groups, Delphi technique and audio recordings. Eight (19.5\%) theses did not state the data collection instrument. In the dissertations, forms was used in $17(6.2 \%)$ studies, scales in 16 (5.8\%), documents 15 (5.4\%) and observation in $22(8.0 \%)$, of which 12 are of the participant type. The data collection instrument was not stated in $30(10.9 \%)$ dissertations.

Regarding data analysis, 18 (43.9\%) theses and $157(57.5 \%)$ dissertations did not clearly state the method used for data analysis.

When information was taken from the front pages, inside back cover and the abstracts, it was also possible to observe their presentation. It may be identified that the dissertations' and theses' presentation is similar to the covers and inside back covers of publications from these three universities, in particular of more recent studies. However, the layout of the abstract does not seem to have an institutional standard or norm, for example, in relation to the number of words and/or text characters, or the presence or number of key words/descriptors, among others.

\section{DISCUSSION}

ICBAS is the institution which produces the highest number of Masters and Doctors in nursing in Portugal, although the difference of the period when the courses began in the institutions is not significant. ICBAS began providing Master's courses in 1993, and the doctorate in 2001, while UCP started its Master's course in 1991 and the doctorate in 2004. These dates also apply to the beginning of the postgraduate courses at UL.

In this study, for determining the topics of the Master's dissertations and doctoral theses, the researchers considered the words in the titles, as these must be made up of words, expressions or phrases which designate the subject or the content of the publication, ${ }^{8}$ that is, describe the content published, appropriately, in few words. In titles, the presentation of information between brackets and expressed in abbreviated forms must be avoided, except when these are universally known. ${ }^{9}$ Hence, if the title does clearly reveal the study's content, there could be an error of interpretation.

It is noted that topics about the older adult, the family, the adolescent, obstetrics and nursing training stand out in the Portuguese dissertations and theses. In Brazilian research, the topic of nursing training is also one of the most common, in journals of the area, along with the issues of the bases/fundamentals/conceptions of care, the fields in which people work, and professional matters. In research, regardless of the country or region, it is fundamental to be clear regarding what is being researched, for what and for whom the knowledge produced will be, and what its impact will be for society. ${ }^{10}$

The use of keywords is a mandatory element in the presentation of works/studies; these must appear immediately below the abstract, preceded by the expression 'keywords:', separated by periods and terminating, also, with a period. .,11 $^{8}$ The designated keywords must represent the study's content, and be selected, preferably, from a controlled vocabulary, given that they serve for indexing the work/study. ${ }^{8-9,11}$

On average, a quarter of the Master's and doctoral studies present keywords. This average reduces still further when one considers the presence of DeCS/MeSH descriptors. ${ }^{12-13}$ The use of DeCS/MeSH terms signifies the adoption of a single indexing language to be used in the researching and retrieving of topics from the scientific literature, in the sources of information which use these terms, which allow the researcher to recover information with the exact term, which describes a specific scientific content (concept). The terms make it possible for any study to be accessed by the scientific community, when the exact descriptors or correct synonyms of the indexing are used..$^{12}$ The term 'nursing' is little observed in the Master's studies analyzed (6.2\%) and, in the case of doctoral theses whose studies address this field of knowledge, the presence of this keyword/ descriptor was not identified.

In Portugal, legislation stipulated and still stipulates that Master's studies be supervised by specialists of recognised merit, under the title of supervisor, in line with Decree-Law N. 74/2006, as a result of which, the evidence found is justi- 
fied. ${ }^{14}$ Nevertheless, there are studies which do not mention the supervisor, and studies in which the supervisor is mentioned, but his or her academic title is not. In bibliometrics, the supervisor's name and title are necessary for the calculation of the productivity of each researcher, according to Lotka's Law. ${ }^{6}$

The Portuguese institutions which produce Masters and Doctors have few professors who significantly stand out in the supervising of dissertations and theses, and have many professors who participate little. A similar condition is also identified in a Brazilian study, ${ }^{15}$ corroborating Lotka's Law, which determines authors' contributions to the development and progress of science. Thus, it is argued that a large proportion of scientific production is produced by a small number of investigators, while the others (the larger group) are responsible for a small production. ${ }^{6}$

The researchers' preference for investigations of the qualitative type is ascertained, both in the dissertations and theses; this seeks to understand specific phenomena, aiming to reveal the individuals' significations, beliefs, values and attitudes. Such research is concerned with particular responses from specific contexts, based on human actions and relationships, irrespective of when they occur. ${ }^{16-17}$ The interview, considered a qualitative technique, allows access to the meanings attributed by the individuals to the events experienced, ${ }^{18}$ explaining the prevalence identified of this data collection instrument.

Of the qualitative methods, the exploratory and descriptive methods stand out in the nursing dissertations, in Portugal. Phenomenology is also preferred by researchers undertaking Master's and doctorates, as in nursing research in the Americas. ${ }^{19}$ Grounded Theory and action research are also emphasized as methods used in the theses, particularly in those of the interventional research type.

In epidemiological research, the transversal study is one of those used most. ${ }^{20-21}$ This confirms this study's finding, given that, of the quantitative methods, that of the exploratory, descriptive, analytical, transversal type was the most used in the Master's studies. In the doctoral studies, the descriptive correlational type was used most.

An abstract must concisely present the relevant points of the study, so as to state objectives, methodology, results and conclusions in a single paragraph, of 150 to 500 words for academic works such as theses and dissertations. ${ }^{11}$ Information on the methodology, such as the research method, the data collection instruments and the analytical method is absent from a significant proportion of the abstracts of the Master's and doctorate studies analyzed. There are, also, the studies which do not have an abstract.

The theoretical framework is made up of a universe of concepts, principles and categories which systematically form a logical and coherent set of ideas which underlie the development of a particular study. ${ }^{22}$ In the analysis of the theses and dissertations, it may be observed that between $9 \%$ and $34 \%$ of the studies, respectively, state the theoretical framework. This leads us to question whether the researchers use the theoretical framework little or whether they simply do not cite them in the abstracts. Responding to this question, international studies indicate the growing number of nursing research articles, guided by theories not always nursing theories - and emphasize that even when they are implicit, the studies do not always state them. ${ }^{23}$

Considering the results found, there is a panorama of the theses and dissertations produced in Portuguese nursing, in the period 2000 - 2010. Thus, it could be the object of possible studies, compared with production in other countries, both regarding quantities, proportionate to the period, or regarding the various variables and aspects addressed. Thus, it is possible to indicate tendencies, perspectives and relevancies in the ambit of the evolution of the science of nursing in different continents. Equally, the specific characteristics of the productions analyzed in the qualification of Masters and Doctors in Portugal shows their trajectory in terms of competencies in place and important concrete advances as they accompany the evolution of nursing in the world context. As a result, this is reflected in Portugal's educational policies.

In accordance with the methodology, the study limited itself to locating and analyzing the nursing dissertations and theses, and not the investigations produced by nurses, in other areas of health.

\section{FINAL CONSIDERATIONS}

The study identifies the Master's and doctoral studies, totalling 41 theses and 273 dissertations, produced in the period 2000-2010. Thus, it reveals a panorama of the stricto sensu studies of Portuguese nursing. The analysis of the theoreti- 
cal, methodological and bibliometric aspects of the scientific production makes it possible for nurses and professors undertaking research to investigate the specific characteristics of the works, which may be improved in future works, for the quality of excellence of the training of Master's and doctoral students.

The abstract is the first part of a study to be retrieved by the readers. Because of this, it must be constructed completely and concisely, so that the research may be read and cited. In the same way, the descriptors must be indexed and represent the content of the study, so as to allow it to be located in the databases.

\section{REFERENCES}

1. Universidade Católica Portuguesa, Instituto de Ciências da Saúde, Ensino, Mestrados, Mestrados em Enfermagem [online]. Portugal; 2012 [acesso 2012 Jan 16]. Disponível em: http://www.ics. lisboa.ucp.pt/site/custom/template/ucptpl_fac. asp?SSPAGEID=924\&lang $=1$ \&artigoID $=53$

2. Universidade Católica Portuguesa. Instituto de Ciências da Saúde, Ensino, Doutorados. [online]. Portugal; 2012 [acesso 2012 Jan 16]. Disponível em: http://www.ics.lisboa. ucp.pt/site/custom/template/ucptpl_fac. asp?SSPAGEID=926\&lang $=1$ \&artigoID $=94$

3. Universidade do Porto. Instituto de Ciências Biomédicas Abel Salazar, Cursos, Mestrados, Mestrado em Ciências de Enfermagem. [online]. Portugal; 2012 [acesso 2012 Jan 16]. Disponível em: http://sigarra.up.pt/icbas/cursos_geral. FormView?P_CUR_SIGLA=MENF

4. Universidade de Lisboa. Cursos, Cursos PósGraduados, Doutorado em Enfermagem. 2012. [online]. Portugal; 2012 [acesso 2012 Jan 16]. Disponível em: http://www.ul.pt/portal/ page?_pageid=173,182940\&_dad=portal\&_ schema=PORTAL

5. Erdmann AL, Fernandes JD, Lunardi VL, Robazzi MLCC, Rodrigues RAP. O alcance da excelência por programas brasileiros de pós-graduação stricto sensu com doutorado em enfermagem. Texto Contexto Enferm. 2012 Jan-Mar; 21(1):130-9.

6. Urbizagastegui R. A produtividade dos autores sobre a Lei de Lotka. Ci Inf. 2008 Mai-Ago; 37(2):87102.

7. Pizzani L, Silva RC; Hayashi MCPI. Bases de dados e bibliometria: a presença da educação especial na base Medline. Rev Bras Biblio Doc. 2008 Jan-Jun; 4(1):68-85.

8. Associação Brasileira de Normas Técnicas. NBR 6022, Informação e documentação, Artigo em publicação periódica científica impressa, Apresentação [online].
Rio de Janeiro (RJ): 2003 [acesso 2012 Jan 18]. Disponível em: http:/ / www.mestradoadm.unir.br/ downloads/715_abnt_nbr_6022__norma_artigo_ cientifico.pdf

9. Oliveira RM, organizadora. Universidade Presidente Antonio Carlos, Rede de Bibliotecas, Roteiro para elaboração de artigo científico de acordo com a NBR 6022/2003 [online]. Barbacena (MG): 2011. [acesso 2012 Jan 18]. Disponível em: http:/ / www.unipac.br/ bb/documentos/roteiro_elaboracao_artigo2011.pdf

10. Lacerda MR, Labronici LM. Papel social e paradigmas da pesquisa qualitativa de enfermagem. Rev Bras Enferm. 2011 Mar-Abr; 64(2):359-64.

11. Associação Brasileira de Normas Técnica. NBR 6022, Informação e documentação, Resumo, Apresentação [online]. Rio de Janeiro (RJ): 2003. [acesso 2012 Jan 18]. Disponível em: http:/ / www. ufpi.br/subsiteFiles/ppgaarq/arquivos/files/6028Resumo.pdf

12. Biblioteca Virtual em Saúde. Descritores em Ciências da Saúde [online]. 2012. [acesso 12 Jan 2012]. Disponível em: http:/ / decs.bvs.br/

13. U.S. National Library of Medicine, National Institutes of Health, Medical Terminologies at NLM, Medical Subject Headings [online]. 2012 [acesso 12 Jan 2012]. Disponível em: http:/ / www.nlm.nih. gov/medical-terms.html

14. Ministério da Ciência. Tecnologia e Ensino Superior, Diário da República, Decreto-Lei n. 74/2006 [online]. 2012. [acesso 16 Jan 2012]. Disponível em: http:// dre.pt/util/getdiplomas.asp?iddip $=20061323$

15. Lanzoni GMM, Baggio MA, Parizoto GM, Cechinel C, Erdmann AL, Meirelles BHS et al. La teoría fundamentada: un estudio bibliométrico de la enfermería brasileña. Index Enferm. 2011 Jul-Set; 20(3):209-214.

16. Minayo MCS. O desafio do conhecimento: pesquisa qualitativa em saúde. $11^{\mathrm{a}}$ ed. São Paulo (SP): HucitecAbrasco; 2008.

17. Merighi MAB, Gonçalves R, Ferreira FC. Estudo bibliométrico sobre dissertações e teses em enfermagem com abordagem fenomenológica: tendência e perspectivas. Rev Latino-am Enferm. 2007 Jul-Ago; 15(4):645-50.

18. Fraser MTD, Gondim SMG. Da fala do outro ao texto negociado: discussões sobre a entrevista na pesquisa qualitativa. Paidéia. 2004 Set-Dez; 14(28):139-52.

19. Cabral IE, Tyrrel MAR. Pesquisa em enfermagem nas Américas. Rev Bras Enferm. 2010 Jan-Fev; 63(1):104-10.

20. Bastos JLD, Duquia RP. Um dos delineamentos mais empregados em epidemiologia: estudo transversal. Scientia Medica. 2007 Out-Dez; 17(4):229-32.

21. Barros AJ, Hirakata VN. Alternatives for logistic regression in cross-sectional studies: an empirical comparison of models that directly estimate the 
prevalence ratio. BMC Med Res Methodol. 2003 Out; 3:21-33.

22. Polit D, Beck CT, Hungler B. Fundamentos de pesquisa em enfermagem: métodos, avaliação e utilização. 5ª ed. Porto Alegre (RS): Artes Médicas; 2004.
23. Bond AE, Eshah NF, Bani-Khaled M, Hamad AO, Habashneh S, Kataua $\mathrm{H}$ et al. Who uses nursing theory? A univariate descriptive analysis of five years' research articles. Scand J Caring Sci. 2011 Jun; 25(2):404-49. 